\title{
The obligation to supply critical human needs
}

\author{
F. Rochford \\ La Trobe University, Australia
}

\begin{abstract}
Australia's federal Water Act requires the creation of water plans that enable the delivery of sufficient water to meet 'critical human needs' This obligation does not create any individual right, although a state may attempt to argue a failure to provide critical human needs as a basis for challenging the Plan. This paper considers the origin of this requirement, the way in which it is intended to be operationalised, and the potential problems in the prioritisation of this requirement. It then considers the creation of a right to water with more content, and the preconditions for establishing that right in Australia.
\end{abstract}

Keywords: water, human rights, law, legislation.

\section{Introduction}

International rights discourse has accepted the inclusion of a human right to water. Australia, along with many other countries, has ratified the international agreements mandating protection of such a right. However, the implementation of such a right is a matter for legislation. To date, as the management of water has been a matter of state competence, there has been relatively little contention as to the scope of such a right in Australia. The federalisation of water and the subsequent passage of the Water Act 2007 (Cth) have prioritised 'critical human needs' in the development of Basin Plans for allocation of water, but within a general framework of creating a market for water. This paper considers the capacity the 'human right' to water operationalized in a market framework, to be a useful conceptual tool. It considers the key tensions in implementation of the right within market paradigms and in the context of ubiquitous governance principles in Australia and many other western industrialised nations. 


\section{A 'human right to water'?}

Recognition of water as a human right occurred in the United Nations Committee on Economic, Social and Cultural Rights in 2002 and a right to access food and water is acknowledged in a range of international instruments [1]. The International Covenant on Economic, Social and Cultural Rights at paragraph 2 provides that 'the human right to water entitles everyone to sufficient, safe, acceptable, physically accessible and affordable water for personal and domestic uses'. Article 10 of the 1997 United Nations Convention on the Law of the Nonnavigational Uses of International Watercourses requires that 'special regard [be] given to the requirements of vital human needs' by 'providing sufficient water to sustain human life, including both drinking water and water required for production of food in order to prevent starvation.' However, the nuanced approach to the question of allocation of scarce resources is more accurately described in the 2001 Bonn Conference on Freshwater which directed that "water should be equitably and sustainably allocated, firstly to basic human needs and then to the functioning of ecosystems and different economic uses including food security.' In that brief statement key concepts such as 'equity', 'sustainability' 'functioning' and 'security' import significant political discretion and potentially neutralise the concept of a human right to water.

\section{Legislating human rights}

Australia's commitment to international obligations is an obligation of the Federal Government, since the External Affairs power is within Federal government constitutional competence at Constitution placitum 51(xxix). However, commitment to international agreement is not sufficient to create a binding obligation; the international agreement must be transformed into domestic law. Where the Constitutional competence has been activated by the enactment of legislation purporting to be based on accession to the Convention or International Agreement (as opposed to one of the other bases for a nexus to external affairs) the key question is whether the relevant law is reasonably capable of being considered appropriate and adapted to implementing the treaty (Richardson $v$ The Forestry Commission (1988) 164 CLR 261). In Victoria $v$ Clth (Industrial Relations Case) (1996) 187 CLR 416 at 487 the majority of the High Court of Australia noted that

[t]o be a law with respect to 'external affairs', the law must be reasonably capable of being considered appropriate and adapted to implementing the treaty. Thus, it is for the legislature to choose the means by which it carries into or gives effect to the treaty, provided that the means chosen are reasonably capable of being considered appropriate and adapted to that end.

If the Federal Government did choose to enliven a treaty obligation by implementing it in domestic law, that law would be Constitutionally invalid only 
if a deficiency in implementation was so substantial that it could not be characterised as a law implementing the Convention; or if, coupled with other provisions of the law, it would be substantially inconsistent with the Convention.

However, the manner in which this constitutional competence was asserted and supported by the Federal government in the enactment of the Water Act 2007 (Cth) was not through reliance on human rights conventions, but on a 'hotchpotch' of Constitutional powers [2] including the External Affairs power, but the External Affairs power was related to the Commonwealth's commitment to the environment. The Water Act has as its primary purpose the development of a Basin Plan which is to be developed according to the general basis set out in s.21 of the Act: it is to give effect to relevant international agreements, and having regard to '(i) the fact that the use of Basin water resources has had, and is likely to have, significant adverse impacts on the conservation and sustainable use of biodiversity, and (ii) the fact that the Basin water resources require, as a result, special measures to manage their use to conserve biodiversity' (Water Act 2007 (Cth) s.21(2)(a)). In other words, the Constitutional basis of the Act, where it is founded on the External Affairs power, must prioritise commitments made pursuant to environmental conventions: The Basin Plan is also required to '(a) promote the wise use of all the Basin water resources; and (b) promote the conservation of declared Ramsar wetlands in the Murray-Darling Basin; and (c) take account of the ecological character descriptions of (i) all declared Ramsar wetlands within the Murray-Darling Basin; and (ii) all other key environmental sites within the Murray-Darling Basin prepared in accordance with the National Framework and Guidance for Describing the Ecological Character of Australia's Ramsar Wetlands endorsed by the Natural Resource Management Ministerial Council (Water Act 2007 (Cth) s.21(3)).

The Water Act 2007 (Cth) s.86A(1) prioritises critical human water needs:

the Basin Plan must be prepared having regard to the fact that the Commonwealth and the Basin States have agreed:

(a) That critical human water needs are the highest priority water use for communities who are dependent on Basin water resources; and

(b) In particular that, to give effect to this priority in the River Murray System, conveyance water will receive first priority from the water available in the system.'

'Critical human water needs' are defined in s.86A(2).as 'the needs for a minimum amount of water, that can only reasonably be provided from Basin water resources, required to meet:

(a) Core human consumption requirements in urban and rural areas; and

(b) Those non-human consumption requirements that a failure to meet would cause prohibitively high social, economic or national security costs.'

The amount of water required to fulfil this requirement in the Basin is assessed by the Murray Darling Basin Authority as 77 GL for Victoria, 61 
gigalitres (GL) in New South Wales and 204 GL for South Australia. More problematically, conveyance water is prioritised, and it amounts to 1,596 GL for each 12 month period. Quality of water is also assessed under the Plan, and this is clearly based on requirements for potable water supplies.

\section{Priority mechanisms and absolute rights}

Although the right to drinking water and basic sanitation is a well-accepted minimal scope of a right to water, there is a significant penumbra in relation to consumptive uses of water, which, for the sake of argument, we could assign thus:

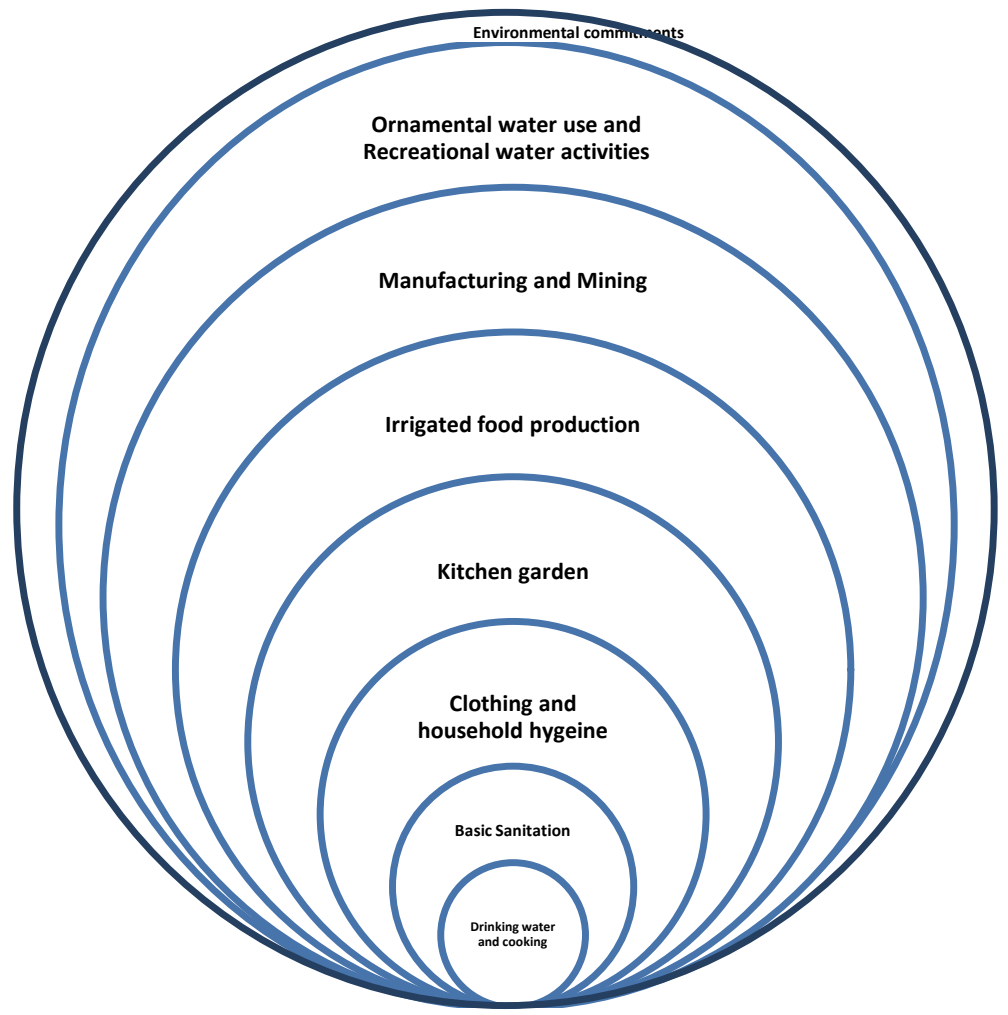

The assignment of water for non-minimal consumptive usages is problematic for several reasons:

1. Actual water usage in penumbral categories varies massively, requiring prioritisation within categories. For instance, within the category of irrigated food production water might be rationed according to the national food priorities, the permanence of the infrastructure investments (for instance, permanent plantings might be prioritised over 
annual irrigation crops) and the cost of delivery to some irrigation areas both in terms of infrastructure costs and in terms of water losses.

2. Delivery of water in some geographical regions generates massive loss of water in itself, since it relies on 'natural water carriers' (rivers) with the associated losses through evaporation, interaction with groundwater, leakage and seepage.

3. The commitment required for delivery of water to the environment has not been settled, and is thus reliant on a political consensus. Where the Constitutional foundation for the Act is the environmental commitments undertaken by the Federal government, this creates the potential for judicial challenge to apportionment of water.

Even within the core category there are issues; water is capable of differentiation on a number of bases - quality, degree of treatment, price, quantity and security of supply. However, it is generally conceded that the minimal requirement is that the state ensures for its citizens a reliable water source for drinking and hygiene. Nevertheless, it is clear that there are many geographical regions in Australia, outside the reticulated systems in urban areas and regional towns, in which water is accessible only through the use of private infrastructure - water tanks, dams and bores with associated private filtration systems, and tank water deliveries sourced from other geographical regions. This issue is rarely a matter for commentary, unless it involves otherwise politically significant questions - for instance, when it involves communities otherwise disadvantaged by socio-economic measures. For instance, Watarru, in the Anangu Pitjantjatjara Yankunytjatjara Lands, has been in the national news because it has no power since its diesel generators were damaged; and, in consequence, no water [3]. Research relating to remote and rural Aboriginal communities in Western Australia in the past has confirmed the inadequacy of water supplies [4]. In most rural households which are not serviced by municipal authorities, water supply and infrastructure is self-funded and self-maintained. The State undertakes no responsibility for assuring water supply to individual households outside towns and cities; and moreover the issue of 'sustainability' is also becoming part of the discourse in the supply and servicing of potable water supplies in small communities.

\section{Rights and corresponding duties}

The uncertain scope of such a right is problematic from a number of perspectives:

- In political discourse 'rights' assertions encode areas of exclusion guarantees of outcomes. They define and restrict public engagement. When validated by international instruments, rights statements have the potential to become legally enforceable.

- In legal discourse the inability to define such a right makes it difficult to hold institutions to account for failure to comply with such a right. 
- Citizens' expectations of states' delivery of 'rights' increases as the general community standard of living increases. Conversely, states' expectations of citizens' ability to pay for fundamental rights will also increase.

- $\quad$ Significant state infrastructure is necessary to deliver water to citizens. States' priorities vary over time. Since the right to water is undefined, it is a relatively simple political argument to commit resources elsewhere.

The capacity of the state to diminish its commitment to an almost negligible baseline is demonstrated by commentary which identifies as entirely consistent with the human right to water:

1. Disparate measures between different countries may be consistent with compliance with the right.

2. Ensuring access to water is aspirational, insofar as it is acknowledged that acknowledgement of the right to water does not require expenditure to comply with the right.

3. Yet a 'domestic' right to water is expected to enable 'disadvantaged people who need to have the law on their side if their rights are to be respected' [5].

The major outcome of this conceptual uncertainty in the Australian context is the 'invisibility' of constraints on human potable water supply as an issue in the Australian public consciousness. The 'central dynamic' [6] in rural Australia is a disconnect between the concerns of metropolitan communities and those in rural and regional Australia.

In Australia the 'right' to water is recognised primarily through a range of municipal and state programs to require connection and guarantee supply of potable water in communities, to provide alternative payment plans for those having difficulty meeting the costs of water, and to provide pricing controls over the provision of water and water-related infrastructure. There is also a body of public health law which mandates water standards in reticulated water supplies. None of these programs apply to water in non-reticulated systems. Since, in a reticulated system, there is no alternative other than to be connected to the system, it can hardly be considered a 'right'. The obligation to connect and to pay the fees associated with water infrastructure is state-mandated on the basis that if there was a choice not to be connected it would threaten the economic viability of the project as well as the public health measures anticipated by water reticulation and sewerage programs. Tortious, contractual and administrative remedies apply to failures of public authorities to comply with their obligations, but these remedies are not assisted by the acceptance or rejection of a 'right' to water that exists outside ordinary domestic democratic principles. 


\section{Reconciling competing forces}

\subsection{Privatisation and government provision of services}

If there is potential for the rhetoric of human rights in this province, it must be in its capacity to resist other central governance themes which have become ubiquitous in modern Western democracies. These resolve themselves around the retreat of the role of the government in the provision of public services and its replacement with a user-pays framework for services. The Preamble to the European Union Water Framework Directive (2000) (European Parliament and Council 2000) states that ' $[\mathrm{w}]$ ater is not a commercial product like any other but, rather, a heritage which must be protected, defended and treated as such', and it is partly on the basis of that sentiment that the provision of water has not been privatized. However, under the New Public Management framework water authorities have been corporatised. Although municipalities and states continue to ensure provision of water to larger communities, water is provided on a user pays basis, with a significant dividend payable to government. For instance, the Water Act 1989 (Vic) s.122ZH sets out the obligation to provide dividends, which are determined on the basis of water authorities' operating results. Those dividends have varied from $\$ 352.8$ million in 2002-03 to $\$ 72.28$ million in the drought year of 2010-11. Pursuant to principles applied across states, a market for water has developed, rendering policy-based limitations on water transfer subject to Constitutional limitations on constraints on free trade and subjecting the sector to the General Agreement on Trade in Services.

\subsection{Subsidarity and centralisation}

A right to provide water sufficient to comply with the human right to water naturally falls upon local authorities, which are, in turn, established, funded and thus constrained by State governments.

As access to water is essentially a local or regional matter, local or regional government authorities are generally in charge of implementing water services (subsidiarity principle). However, in some countries, difficulties can arise when the government authorities in charge do not have sufficient legal authority-notably financial and fiscal authority-at their level to act autonomously enough [5].

In Australia, as in many other countries, the capacity of municipalities and shires to levy sufficient funds from residents to cover the provision of local services is restricted by the capacity of residents to pay. The centralising tendency in Australian Constitutional law threatens the application of the subsidiarity principle; whereas the obligation to supply potable water falls upon local authorities, they are primarily reliant for their funding on State governments which, in turn, are largely reliant on the provision of funding by way of grants from the Commonwealth government. Moreover, delivery of water 
requires significant infrastructure that cannot be provided by a municipality on a discrete basis. The capacity of State and Municipal authorities to provide water sufficient to enable delivery of sufficient water for even the core right to water is almost entirely dependent on the federal government providing sufficient ongoing financial support. Centralised taxation powers do, in one sense, support the subsidiarity principle by collecting and redistributing tax moneys; however where there is no basic guarantee of a 'human right' to water there is no compulsion for money to be redistributed to this central purpose. Rather, the subsidiarity principle will be undermined by trends to urbanisation and a requirement that communities, to receive support, must be 'sustainable'.

\subsection{Urbanisation, solidarity and 'sustainable communities'}

Even in a developed economy such as Australia, there is a major discrepancy in the provision of water in urban contexts and the provision of water in rural and regional communities. Whereas potable water supplies are assured to townships across Australia, and regulatory and quasi-regulatory mechanisms exist to ensure that individuals and households can access sufficient water for consumption, cooking and hygiene, no such protection exists in rural and remote areas. This gives rise to a tension between the ability of a person to live where they choose and their capacity to access water. The principle of solidarity suggests that there should be a degree of cross-subsidisation, and again the redistributive function of taxation has the capacity to ensure a human right to water to these communities, if a human right to water was a real rather than an inchoate concept.

This is a significant tension in indigenous populations, which experience higher levels of disadvantage than other parts of the Australian community. Many indigenous communities living in remote areas still have variable access to state-provisioned potable water, yet may be lacking the financial capacity to ensure their own access. The relationship between "poverty and geographic locational disadvantage is a very serious issue that we need to grapple with in the short term rather than over the long term,' [7] but the access of rural residents to potable water is often only framed as a human rights issue when it involves identifiable communities such as indigenous communities. Yet rural communities, indigenous and non-indigenous, comprise some of the lowest socio-economic communities in Australia, can have extreme difficulties in accessing water, require the highest level of infrastructure costs to ensure delivery, and are serviced by some of the most parlous municipal authorities.

\section{Conclusion}

As currently conceptualised, the human right to water, expressed at a high level and in amorphous terms, is insubstantial at law and is subject to competing principles with stronger support at governmental level. Whereas there are strong practical constraints on the capacity of the concept of a human right to water to be honoured by every nation, rich or poor, in the same manner, there are few requirements more basic to life. In prosperous countries it is possible to lose 
sight of the failure of governments to assure basic rights, and a reconceptualization of the right to water as a right with specified content capable of legal protection is necessary.

\section{References}

[1] United Nations Committee on Economic, Social and Cultural Rights General Comment No 15 United Nations (2002), United Nations International Covenant on Economic, Social and Cultural Rights United Nations (1966); United Nations Universal Declaration of Human Rights United Nations (1948) art 25.

[2] Twomey, Anne, 'Aspirational nationalism or opportunistic Federalism?' Quadrant October 2007, 38, 40.

[3] Martin, Sarah, 'Gardens prioritised over APY power' The Australian $21^{\text {st }}$ May 2013.

[4] Gracey, Michael, Williams, Peta, and Houston, Shane 'Environmental health conditions in remote and rural Aboriginal communities in Western Australia' (1997) 21 Australia and New Zealand Journal of Public Health 511.

[5] Smets, Henri, 'The right to water in national legislations; Agence Française de Développement 2006, 17.

[6] Holmes, John, 'Impulses towards a multifunctional transition in rural Australia: Gaps in the research agenda' (2006) Journal of Rural Studies 22 $142,147$.

[7] Committee Hansard 4.8.03 p 1193 (QCOSS) cited in Commonwealth of Australia, $A$ hand up not a hand out: Renewing the fight against poverty (Report on poverty and financial hardship) 11 March 2004. 